\title{
Determinate/IndeTerminate Duality: The NeCESSITY of a TEMPORAL Dimension in Legal Classification
}

\author{
WENDY ADAMS ${ }^{*}$
}

The objective of this article is to reconcile the difficulties in legal classification that arise when subject mafter is vieured from a purely spatial, i.c., a no or three-dimensional, perspective. At issue is whether the dynamic complexity oflegal reasoning can be represented lirough a process of static classification. The difficully with traditional approaches to classification is that while legal reasoning makes use of concurrent concepts to resolve issues, classification systems operale with mutuallyexclasive classes that do not permit representation of reiterative reasoning processes

Using the example of the neologism of "propertization, "an issne of increasing concern in the field of intellectial property. the author seeks to demonstrate that a single classification system can represen both the deferminacy and indeterminacy of legal concepts as they are used to resolve legal problems withoul sacrificing the clarity presumably. required for the rule of law to operate. Resolution requires adopting a classification system that makes use of both a remporal and spatial perspective. By. adopting a temporal perspective in addition to a more iraditional spatial perspective, we are able to expand our focus from the products of legal classification to legal classification as a process. We can then examine the dynamic relationship of rilativity between legal concepts as they operate in contex, rather than limiting our analysis in the static relationship of demarcation that exists when legal classes are examined in the abstruct.
L'objectif de cet article est de rapprocher les difficulfés du classement juridique qui surgissem lorsque le sujet est considere d'un poim de vie purcment spatial, c'est-à-dire une perspective $\dot{a}$ devx ou trois, dimensions. Le point controversé est de savoir si la complexite dynamique du raisonmement juridique peut efre representée au moyen d'un processus de classement statique. Le problème des approches traditionnelles au classement est que bien que te raisonnement juridique utilise des concepts concomilants pour régler les problèmes. les sysièmes de classiffation fonctionment avec des categories muluellemen exclusives qui ne permenem pas la reprevenuation de processus de raisommenen réiteratifs.

Se servant de lexemple du néologisme "propricitisation ", question de plus en plus préoccupante dans le domaine de la proprièe intellectuelle. Iauteur cherche à démonirer qu 'un seul système de classification peut représenter à la fois l'aspect déterminant et indéterminam des concepts juridiques utilisés pour régler les problèmes juridiques sans sacrifier la clarté sans doute requise pour assurer la primuuté di droit. Pour résoudre celte question. Il faul adopter un systeme de classification qui fait appel a la fois à la perspective temporelle ef spatiale. En adopumi une perspective remporelle en phas d'une perspective traditionnelle plus spatiale, nous pouvons elargir norre champ des produits de classification juridique à la classification juridique en tant que processus. Nous pourrons alors examiner la relation dinamique de la relativité entre les concepts juridiques foncrionnam en contexte au lieu de limiter notre analyse is la relation statique de dimarcation qui existe lorsque des catigories juridiques som examinies de momicre abstroite.

1 TABLE OF CONTENTS

I. INTRODUCTION ............................ 404

II. Classification of Legal KNowledge $\ldots \ldots \ldots \ldots \ldots \ldots \ldots 407$

III. A SPATIAL ANALYSIS OF "Propertization": Limitations AND ONTOI.OGICAL DiFFICUL.TIES

Faculty of Law, McGill University. Many thanks to G. Kruger, McGill LL.B./B.C.L. 2006, for his research assistance, and to $R$. Macdonald, S. Smith, and N. Kasiter for their comments on earlier drafts. Any crrors and omissions remain my own. 


\section{A TEMPORAL ANALYSIS OF "PROPERTIZATION": THE MUTUALITY

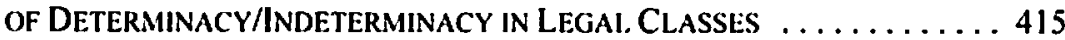 \\ V. ReFraming THE "Propertization" Debate .............420 \\ A. IMPLICIT NORMATIVE TRANSFER IN JUDICIAL \\ REASONING: MONSANTO V. SCHMEISER ............. 421 \\ B. EThical Implications: HaRVARD COLlegil:

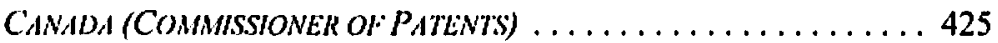

VI. Conci.usion ............................. 427

\section{INTRODUCTION}

The concept of legal classification as a way of representing legal knowledge is difficult to communicate using its own abstract terms. For this reason, some jurists make use of metaphors to explain the relationship between classification and legal knowledge. Common law jurists who see a direct relationship between legal classification and legal reasoning often rely on a mapping metaphor.'

When legal concepts are classified with sufficient delinitional rigour, legal reasoning is a matter of locating the helplul "you are here" signpost in the midst of a given legal problem. Resolution of a legal problem is dictated by its classification; factual circumstances are matched to a content-based class and resolution of the legal issue proceeds by applying the contents of the class to the problem. Most importantly for those who advocate the utility of a metaphor of mapping, just as a topographical border demarcates mutually exclusive locations (even though the border itself may change), legal concepts must be constructed as mutually exclusive classes if the rule of law is to prevail. Like cases cannot be treated alike if the initial classification process is inconsistent between cases. Concurrency of legal concepts in two or more classes would lead to indeterminacy of legal classes and inconsistency in legal reasoning.

While most common law jurists would accept the significance of legal classification, many would object to the presumptive simplicity of a mapping metaphor that purports to reflect the complexity of legal reasoning with a two-dimensional spatial representation. Legal reasoning often requires the simultaneous application of multiple concepts that defy classification. "You are here" on a two-dimensional plane such as a map is limited to a single location. In contrast, the complexity of legal reasoning requires jurists to locate themselves. metaphorically, in two or more places at once. A mapping metaphor cannot account for the manner in which multiple legal concepts must be applied simultaneously to resolve legal problems.

No real disagreement can exist that legal knowledge can be represented and understood in categorical form. As Stephen A. Smith states, and as most jurists (not to mention cognitive scientists) would agree, legal classification is part of the process of acquiring and developing legal knowledge. 'Although classification criteria are always open to challenge, legal

Cartography is a popular choice of metaphor, perhaps due to the jurisdictional orientation of most systems of legal education.

Stephen A. Smith, "A Map of the Common Law?" (2004) 40 Can. Bus. L.J. 364 at 365. 
knowledge is predicated upon content-based classes. The question is whether the complexity of legal reasoning is best understood as the application of mutually exclusive classes alone, or whether these discrete classes are necessarily complemented by a number of overlapping concepts that defy classification. Accordingly, disagreement as to the appropriateness of a mapping metaphor is actually disagreement concerning the nature of the relationship between legal classification and legal reasoning. Those who reject the mapping metaphor are, in effect, rejecting the argument that law can be represented fully in the form of mutually exclusive legal classes.

Assuming without deciding that legal reasoning requires the application of overlapping legal concepts, that overlapping concepts lead to a certain degree of legal indeterminacy. and that legal indeterminacy in turn has an adverse impact on the application of the rule of law, the modest objective of this analysis is simply to reconcile these seemingly incompatible assumptions. One solution would be to propose that legal indeterminacy does not affect the rule of law, but the purpose of this analysis is to reconcile conflicting positions rather than argue in favour ol onc or the other. Another solution, briclly stated, is to propose that reconciliation is possible by recognizing that legal categories are both determinate and indeterminate.

The proposition is not as paradoxical (nor as unhelpful) as may first appear, particularly if reference is made to yet another conceptual metaphor to explain a legal concept. Recall an elementary concept from physics known as wave-particle duality, whereby entities exhibit both wave and particle aspects. ${ }^{3}$ An experiment that demonstrates the particle-like nature of an entity will not also show its wave-like nature, and vice versa. For example, the wave characteristics of light are demonstrated by processes such as diffraction and polarization. while light's particle characteristics are demonstrated by its photoelectric effect. Thus, the properties of light from the perspective of physics are best understood in terms of the concept of complementarity, whereby no single model is suflicient to explain observed phenomena. ${ }^{4}$ In some circumstances, light is best understood in terms of wave-like properties, while in other cases it is better to think of light in terms of particle-like properties; context is everything.

Just as the concept of wave-particle duality in physics provides for the coexistence of both wave-like and particle-like properties in entities, so too does this concept of duality permit recognition of the conceptual possibility of determinate/indeterminate legal classification. In the same manner that |a particular context of an experiment will reveal either wave or particle characteristics of the same entity, so too will the context of legal analysis reveal determinacy or indeterminacy in the same legal class. The signilicant variable is not the time at which the class is examined, but rather, the manner in which the class is observed. A traditional, spatial approach to legal classification will reveal determinate characteristics in legal classes, given that decision rules in the classification process are designed to provide for demarcation. In response to the claim that spatial legal classification does not take account of the complexity of legal reasoning, the author proposes a non-traditional temporal

John Daintith. ed.. Oxford Dictionany of Plysics. Sth ed. (Oxford: Oxford University Press. 2005) s.v. "wave-particle duality."

lbid., s.v. "complementarity." 
perspective that reveals the indeterminacy of legal classification. Just as entities, however, possess characteristics of both waves and particles, so can determinacy of legal classes from a spatial perspective coexist with indeterminacy from a temporal perspective; neither one displaces the other.

One important point to note is that a temporal perspective is not an historical perspective. An historical perspective is diachronic in that it examines how legal classification has changed over time. Thus, an historical perspective is necessarily spatial in that it represents an accumulation of a series of spatial observations. In contrast, a temporal perspective is synchronic in that legal classification is observed at a given point in time that need not be a different point in time than one chosen to observe a legal classification from a spatial perspective. It may be the case that observation cannot take place from both a temporal and spatial perspective simultaneously, but to explore this concept requires reference to increasingly complicated concepts in physics that exceed this author's limited capabilities. ${ }^{5}$

This analysis begins in Part II with a brief summary of the basic arguments concerning classification schemes as a method of representing legal knowledge. Part III demonstrates the limitations of a purely spatial approach to legal classilication with an example drawn from a relatively recent taxonomic debate, that of the "propertization" of intellectual property. The neologism of "propertization" is a response to the current expansionary trend in intellectual property protection. A claim of "propertization" is based on the assumption that intellectual property and property per se represent mutually-exclusive legal classes; expanding the scope of intellectual property protection results in the unjustified "propertization" of intellectual property as a legal class. The difficulty with the debate is that in framing their arguments, the parties rely on a purely spatial approach to classification and thus tend to focus on the formal transgression of definitional boundaries in the abstract instead of the use made of intellectual property in context. Part IV demonstrates that this definitional impasse can be overcome by adopting a temporal approach to classification where the focus is not so much what intellectual property is in the abstract, but rather what intellectual property does in the context of market transactions involving intellectual assets. Part V then places concerns with "propertization" within the context of legal reasoning in dealing with claims for patent protection for biotechnological innovations. Applying a temporal approach to legal classification of intellectual property and property, certain deficiencies of legal reasoning can be identified. The first is the manner in which exclusive reliance on spatial analysis in the face of concurrency of legal concepts produces unacknowledged sites of normativity that affect legal reasoning in unexpected ways. The second is the extent to which a spatial perspective of intellectual property precludes recognition of its proprictary attributes and concomitant ethical concerns other than those traditionally associated with the balance in intellectual property law between public access and private gain.

5 For those who are interested, reference may be made here to the uncertainty prineiple, which provides that one cannot delermine with accuracy both the position and momentum ol a particle. See ibid., s.v. "uncertainty principle." 


\section{Classification of legal Knowledge}

Peter Birks has perhaps devoted the most attention to developing a classification scheme for the common law, most notably the law of obligations. ' Birks is also a strong advocate of the two-dimensional spatial metaphor of mapping. He uses this metaphor not only to describe the knowledge structure of the common law, but also to present a normative claim for greater precision in common law taxonomy. For Birks, a legal problem, like a physical person, can only be in one place at a time. Content-based legal classes are mutuallyexclusive, and classification must proceed accordingly if law is to function properiy. A rationalized legal taxonomy provides the necessary definitional rigour without which consistency in law and, therefore, the rule of law, could not exist. Thus, the definitions used to construct legal classes might be arbitrary to a certain extent, but this deficiency is offset by the resulting gains in stability and consistency. ${ }^{7}$ One hopes, however, that through the use of rigorous taxonomic debate, arbitrary distinctions can be minimized. ${ }^{8}$

In contrast to Birks, Stephen Waddams is skeptical of the metaphor of mapping as applied to understand the relationship between legal classes and legal reasoning. His resistance is based primarily on the complexity of legal reasoning. Legal knowledge cannot be mapped because legal reasoning does not proceed with reference to mutually exclusive legal classes. Legal concepts do not necessarily exist independently of each other, and cases are often decided on the basis of a number of legal concepts operating concurrently. ${ }^{9}$ The difficulty with mapping metaphors is that while concurrency is inherent in the process of legal reasoning, mutually exclusive legal classes derived from mapping projects do not allow for jurists to locate themselves in two or more places at the same time. Given that a legal issue

Sec, e.g., Peter Birks, ed., English Private Law, vol. 2 (Oxford: Oxford University Press, 20100).

7 Peter Birks, "Definition and Division: A Mediation un /ustinuses" in Peter Birks, ed., The Classification of Obligatious (Oxford: Oxford University Press, 1997) I at 6.

B For Birks, the common law legal tradition has difliculty developing a suitable classification sysicm because common law lawyers have abandoned the taxomomic debate so central to civilian legal traditions. The common law is amenable to the Gaian taxonomy of persons, things, and actions, but common law lawyers reject the logic of this classification system. They are content, instead, to rely on the organizing principle of the alphabet. Birks also identifies a second problem proceeding from the common law's lack of coneern with taxonomy. To demonstrate his point, Birks temporarily mixes the metaphors of cartography and compatible sofiware (or what we would now call "open sysiems"). The common law lacks an organizing principle capable of supporting a meaning ful system of classification. Thus, legal knowledge in the common law exists as a series of isolated legal doctrines. Jurists are capable of working at a sophisticated level within these isolated classes, but to adopt the melaphor of incompatible sothware, they cannot transfer the data of a legal problem to a different legal class. The classes do not make use of compatible software. and thus lawyers cannot devise solutions to legal problems based on ecommon law doctrines which exist outside of their particular specialty. As l3irks writes: "If lawyers cannot move efliciently across the law, the law itscll cannot be reliably applied. Individuals must thien lose cases they should have won or. more commonly. settle or abandon claims on wrong ad vice" (ibid at 34). In other words, geod law yers need gexd maps and compatible soflware, and taxonomic debate within the common law tradition is a wortlawhile excreise in carography and systems design. Lawyers should seck to introduce greater order into the common law legal tradition by constructing well-defined two-dimensional legal classes that. like jurisdictions on a territorial map, are joined by contiguous boundaries that do not intersect.

- Stephen Waddams, Dimensions of Privale Law: Cotcgorics and Concepts in Anglo-American l.egal Keasoning (Cambridge: Cambridge University Press, 2003) at 13. 
cannot be assigned to any one concept (or class) alone, the metaphor of mapping is illadvised..$^{10}$

Thus, Waddams argues against the utility of Birks' mapping project on the basis that twodimensional representations of legal knowledge cannot account for the dynamic and reiterative nature of legal reasoning. Geopolitical territories are often in flux, and physical landscapes do change over time. Cartographers, however, may be reasonably certain that they are accurately mapping a particular terrain at any given time." More significantly, they can be certain that the action of mapping alone does not change the underlying physical terrain. ${ }^{12}$ The same cannot be said of the relationship between jurists and law. As Waddams notes, unlike the field of cartography, in law one often has difficulty distinguishing the map from the terrain. ${ }^{13}$ Sometimes legal classification represents existing legal knowledge, at other times classification is used to create new legal knowledge. As Edward Levi succinctly stated, "the classification changes as the classification is made."

Arguing from a common law legal tradition, Waddams objects not only to the metaphor of mapping, but also to similar legal classification schemas in general, at least to the extent that the system of classification requires that each legal issue be resolved with reference to a single conceptual location. ${ }^{15}$ Such exclusivity, according to Waddams, is incompatible with the nature of common law reasoning. Smith concurs with this assessment, noting that if a common law map was indeed faithful to the complex common law terrain, the map would contain thousands, perhaps even millions, of sui generis categories. ${ }^{16}$ This occurrence would defeat the purpose of legal classification, which is to represent, rather than render, law as a system of knowledge. Similarly, cross-referencing between classes would not address the problem. As Waddams argues, the bibliographic form of classification is inapplicable to law. ${ }^{17}$ A catalogue entry for a book can have cross-references to multiple classes (subject headings) because a book is not a class but an instance of a class. If we were to characterize each legal instance not already represented by a class as a class in its own right, this would be equivalent to replacing the subject headings in the Library of Congress catalogue with the actual titles of each catalogued entry. Such a knowledge structure lacks an organizing theme and thus provides no insights into the origins and nature of legal knowledge.

To conclude, however, that legal reasoning cannot be mapped onto a two-dimensional plane does not preclude the possibility that legal knowledge can be represented in categorical form. Geoffrey Samuel, for example, suggests that a three-dimensional model could be used to represent the complex process of legal reasoning described by Waddams. To demonstrate such a model, Samucl provides as a useful example a set of litigation facts that could concurrently pose problems in public and private law, and exist simultaneously as a problem

Ibid. al 226.

But see Mark Monmonier, /low to Lie with Mops, 2 d ed. (Chicago: University of Chicago Press. 1996). This presumes, of course. that constructivist perspectives are for the moment irrelevant. Stupra nole 9 at 226. Ibid, at 15, citing Edwarcl I. Levi, An Introducfion to Legal Reasoning (Chicago: University of Chicago Press, 1949) at 3.

Waddams, ibid at 232. 
in both contract law and property law. Although Samuel acknowledges that Waddams is likely to reject even a three-dimensional schematic model, the model nonetheless demonstrates the possibility of representing the concurrent application of legal concepts without sacrificing the utility of classification as a representation of legal knowledge. ${ }^{18}$

Both Birks' common law mapping project and Samucl's proposed three-dimensional model demonstrate that legal classification is a matler of perspective. Both two-dimensional and three-dimensional miodels address classification by focusing on a particular legal class. or combination of classes, in spatial terms. Each legal class has a well-defined boundary demarcating between the single legal concept that belongs within the class and the remaining legal concepts in the legal system that do not belong within the class but, instead, have an equally well-demarcated class of their own.

In terms of the process of legal reasoning, at the simplest level we have a one-to-one relationship between a set of factual circumstances, which is an instance of a class, and the class itself, which represents a single legal concept intended to govern all instances of the class. We can account for this relationship with a two-dimensional view of classification whereby the relevant legal class is represented as a flat squarc. The rule of law prevails by characterizing a like case of factual circumstances as an instance of this class, to be resolved by reference to the single legal concept represented by the class.

At the next level of complexity we have a one-to-many relationship between a set of factual circumstances as an instance of two or more classes, where cach class represents a different legal concept. We can account for this relationship with a three-dimensional view of classification whereby the flat square becomes a cube representing up to six legal classes. The rule of law prevails by characterizing the factual circumstances as instances of multiple classes, to be resolved by reference to the multiple legal concepts represented by the classes. Note, however, that in this example a legal class remains limited to a single legal concept, and that the legal classes, or sides of the cube, may apply concurrently but the concepts do not overlap since each legal class, or side of the cube, contains only one concept.

Classification becomes a challenge only when we must accomplish that which Waddams asserts is not possible, which is to locate the reiterative and interdependent relationship between multiple legal concepts within a single class in a manner that retains the definitional integrity and, thus, determinacy of the class. Note that the problem here is not the simultaneous application of multiple classes, such as the classes of contract and tort to a set of factual circumstances, as this is simply the concurrent application of two discrete classes and can be accommodated in a three-dimensional spatial representation such as Samuel's cube described above. Nor can the conceptual difficulty be resolved by having one class for the legal concept of contract. one for the concept of tort, and one for the concept of contract/tort. Hybridism would merely return us to the unwieldy map of sui generis classes referred to by Smith. 
The challenge is to conceive of a manner in which a single class applied in the process of legal reasoning can represent a dynamic relationship between concepts, such as the concepts of "contract (or consent)" and "tort (or wrongs),"19 and yet still retains an organizational structure capable of representing legal knowledge consistent with the rule of law. Contentbased classification requires decision rules for placing legal concepts within a particular class, and these decision rules cannot be arbitrary if the rule of law is to include both certainty and faimess. Classification criteria must be justified, and it is these justificatory rationales that account for the mutually exclusive nature of legal classes. A rationale justifies nothing if the end result is that a legal concept can be what it is and what it is not at the same time, for this would amount to a justification of mutually exclusive outcomes.

Is it possible then to represent concurrency of legal concepts, which for the sake of argument are predicated upon different justificatory rationales, within a single, non-hybrid legal class? This is what we must do if classification is to represent, and not simply render, the complexity of law as a system of knowledge. As stated earlier, the issue is one of perspective. The solution is to perceive of legal classes from a temporal rather than spatial perspective in order to observe whether concurrency of legal concepts has resulted in reconfiguration of one or both concepts. The advantage of adding a fourth, temporal dimension to the traditional spatial analysis, even a spatial analysis existing in threedimensional form, is that the primary focus is no longer on legal classes as products but classification as a process.

Consider Waddams' statement: "The contents of legal categories ... cannot be itemized, sorted, or enumerated."20 Consider also his description of legal concepts as working concurrently, cumulatively and, most significantly, in a complementary fashion, in that each concept supplements the meaning of other concepts. We cannot take account of the concurrency of legal concepts within a single class by viewing legal classes in a spatial form, whether two-dimensional or three-dimensional; in each case, each legal class has been confined to a single legal concept.

We can, however, identify and analyze concurrency of legal concepts within a single class by adopting a temporal perspective where the emphasis is on relativity rather than demarcation between legal concepts. If we are to take seriously the utility of legal classification, that is to say, the question of whether classification can properly represent legal knowledge, we need to look not just at classes as products of legal classification, but at the process itself. If one agrees with Waddams (and Levi), legal classifications are dynamic and thus always in flux. At no point in time (as opposed to space) is the content of a legal class necessarily fixed. On the other hand, once a spatial classification is located, the contents of the spatial class (as opposed to the temporal process) are fixed. As with the observation of waves and particles in the same entity, whether one needs to make use of a temporal or spatial analysis of a legal class will depend upon the nature of the task. Legal reasoning does not operate by reference to a spatial analysis alone, although it often appears that this is the case. A spatial analysis is simply the necessary stopping point that allows us 
to distinguish, as required, between legal classes as products and legal classification as a process.

A temporal perspective brings a much-needed focus on the process of legal classification as a more complete way of representing legal knowledge in categorical form. The emphasis is on the experience of contact and exchange between legal concepts as they operate concurrently in a given context. ${ }^{21}$ For legal classifications predicated upon modalitics of resource allocation, as will be discussed in the next Part, perhaps the most significant context is that of market transactions in intellectual assets. When we understand legal classification as having both a spatial and temporal dimension, we can sec that the representation of legal knowledge is derived not only from a taxonomy predicated upon justificatory rationales, but also from the process of encounter and mediation between the spatial form (as a legal class) and temporal function of legal concepts in the context of market transactions.

Under these conditions, concurrency of legal concepts within a single legal class is not an obstacle to classification but, instead, is one method by which representation of legal knowledge takes place. Overlapping concurrency exists between any number of legal concepts in the temporal dimension, but it does not necessarily follow that a given legal class containing one of these legal concepts will also manifest concurrency in the spatial dimension. Again, with reference to the concept of wave-particle duality and the manner in which the type of experiment determines the nature of the observation, we will see determinacy in a legal class when the circumstances require, just as we will see indeterminacy in overlapping legal concepts when this is required. When application of the rule of law presumptively requires determinacy, a spatial analysis will demonstrate characteristics of determinacy in a given legal class. When legal analysis requires instead that indeterminacy be acknowledged, a temporal analysis will demonstrate an exchange of characteristics between multiple legal concepts. Given the determinacy/indeterminacy duality that exists in relation to each legal concept and the legal class to which it has been allocated, presumptive necessity for determinacy in applying the rule of law does not preclude analysis of indeterminacy from a temporal perspective.

\section{A SPATIAL ANALYSIS OF "Propertization": Limitations and ONTOI.OGiCAI. DifficUl,TiEs}

The limits of spatial analysis as a method of representing legal knowledge can be illustrated by examining the nature of the legal classes of intellectual property and property per se. Intellectual property as a legal class is typically characterized as a statutory grant of a negative right. 22 This characterization is derived from the prevailing rationale of

21 The focus on encounter and exchange is adapted lrom the work of anthropologist François Laplantinc and literary theorist $A$ lexis Nouss in developing an epistemology of mitissage. Stated simply (very simply), méfissage is a way of knowing that rejects exclusive reliance on cillegorical thinking, by which is meant the manier in which meaning is ascribed in accordance with a system of either/or binary classificution. Set François Laplantine \& Alexis Nouss, le' misissage (l'aris: Flammarion, 1997).

22 For example, in Canada sec, e.g. Harward College v. Cancula (Commissioner of Patents), 2002 SCC 76, [2002] 4 S.C.R. 45 at para. 64, Binnie J. [Hanard College]: "While s. 44 (now s. 42) of the Patent Act gives the owner, as against the rest of the world, "the exclusive right. privilege and liberty of making. constructing and using the invention and selling it to others to be used ${ }^{\circ} .$. and in that respect is framed 
utilitarianism, which justifies intellectual property rights as time-limited statutory monopolies necessary to address the public goods nature of intangible assets. ${ }^{23}$ For example, a patent provides the holder with the right to exclude others from making, using, or selling the patented object. A patent does not grant any rights in the subject matter of the patent itself. ${ }^{24}$ This negative right to exclude is narrower in scope than the rights granted by property. As for property, an accepted characterization of the incidents of ownership in common law includes: the right to possess, use, and manage; the right to control the income and capital; the right to security; rights or incidents of transfer; the absence of a limiled term; prohibition against harmful use; liability for execution to satisfy one's creditors; and the incident of residuarity."

The appropriate classification of intellectual property and property has not attracted the degree of ontological controversy one sees with other definitional disputes, such as the common law debate concerning the appropriate boundary (or lack thereof) between the concepts of tort and contract. ${ }^{26}$ This is subject to change, however, as a potentially destabilizing neologism, "propertization," enters the lexicon of intellectual property analysis." The term originated in the beginnings of the recent expansionary trend of intellectual property protection. Those who argue against expansive protection claim that courts and legislators have "propertized" intellectual property by extending the scope of protection beyond the limits set in place by one or more justificatory rationales, of which utilitarianism predominates. Intellectual property as a legal class appears to be approaching functional equivalency with the rights of exclusion and control granted in the form of property rights.

Propertization is thus viewed by its opponents as a process responsible for blurring the distinction between, and thus the meaning conveyed by the legal classification of intellectual property and property. On the other hand, those who argue in support of the expansionist trend insist that the increased scope of rights, particularly in terms of subject matter, are

as a positive right, its effect is essentially to prevent others lrom pratising an invention that, but for the patent monopoly, they would be permitted to practise" [cmphasis in original].

See Peter S. Mencll, "Intellectual Property: General Theories" in Boudewijn Bouckacrt \& Gerrit De Geest, tels., Encychopedia oflan' amd kcomomics, online: <littp:/encyclo.findlaw.com/l600book.pdfs. Sec, e.g. Patem ACt, 35 U.S.C. \$ 154(a)(1) (2000): "Every patem shall contain a ... grant to the patentec ... of the right to exclude others from making, using, offering for sale, or selling the invention." A.M. Honoré, "Ownership" in A.G. Guest, ed., Oxford Essags in .Jurisprndence (London: Oxford University Press, 1961) 107 at $112-24$.

in Sec, e.g., Grant (jilmore, The Death of Contract (Columbus: Ohio State University Press, 1974).

$=\quad$ See, e.g. Wendy J. Gordon. "An Inquiry into the Merits of Copyright: The Challenges of Consistency, Consent. and Encouragement Theory" (1989) 41 Stan. L. Rev. 1343; Jessica Litman, "The Public Domain" (1990) 39 Emory L.J. 965; Frank H. Easterbrook, "Intcllectual Property is Still Propenty" (1990) I 3 Harv. J.L. \& Pub. Pol'y 108: Stephen L. Carter, "Doses it Matler Whether Intellectual Property is Property?" (1993) 68 (hicago-Kent L. Rev. 715; Timothy J. Brennan. "Copyright, Property. and the Right to l)eny" (1993) 68 Chicago-Kent L. Rev. 675: Randal C. Picker. "From Edison to the Broadeast Flag: Mechanisms of Consent and Refusal and the Propertization of Copyright" (2003) 70 U. Chicago L. Rev. 281: Michael A. Carrier, "Cabining Intellectual Property Through a Property Paradigm" (2004) 54 Duke L.J. I; Richard A. Lpstein, "Liberty versus Property" Cracks in the Foundations of Copyright Law" (2005) 42 San Dicgo L. Rev. 1; Peter K. Yu, "Intellectual Property and the Information Lcosystem" [2005] Mich. St. L. Rev. I; Mark A. Lemley, "Properny, Intellectual Property, and Free Riding" (2005) 83 Tex. L. Rev. 1031; Michael Pulos, "A Semiotic Solution to the Propertization Problem of Trademark" (2006) 53 UCLA L. Rev. 833. 
necessary to deal with the unique features of innovation in new fields of technology. ${ }^{2 *}$ They admit that the scope of protection is increasing, but disagree that this results in a process of propertization. Instead, they argue that increased protection is not only necessary in response to the particular challenges presented by new lechnologies, but also fully consistent with the accepted legal classification of intellectual property as time-limited rights that fall short of the types of rights granted in relation to property.

Thus, the parties characterize intellectual property rights as falling on one side or the other of an is/is not spatial classification that assigns property and mere negative rights to exclude in mutually exclusive legal classes. The question posed is what intellectual property is, and not what intellectual property does. This frames the propertization debate in terms that necessarily focus attention on intellectual property and property in spatial form as products of legal classification based on one or more accepted justificatory rationales. Little or no attention is given to the processes through which these legal classes acquire meaning, not only from a given justificatory rationale, but also from the manner in which methods of exclusion as legal concepts function concurrently in market transactions involving new forms of technology.

This distinction between the form and function of protection is subtle but significant. A functional analysis identifies market functions typically associated with the legal class of property, and assesses whether associating these functions with the class of intellectual property removes the distinction between, and thus the meaning derived from, the legal classification of these concepts as a representation of legal knowledge. This is a different issue entirely than the question of whether such functions are consistent with the accepted definitional distinction between the forms of intellectual property and property as legal concepts assigned to different legal classes based on their justificatory rationales. In the final result, the answer to both questions may be the same, but the analytical distinction exists and must be examined before any such conclusions can be drawn.

Participants in the propertization debate do not necessarily advocate that the content of a legal class such as intellectual property cannot change. The difficulty is the assumption that the process of reclassification involves reference to a single source of normativity, that of one or more accepted justifidatory rationales. If the classification of intellectual property proceeds in accordance with limilations sel in place by onc or more accepted justificatory rationales, then legitimate expansion of protection requires that the scope of protection remain consistent with the expression of intellectual property as a single legal concept assigned to a particular legal class. If any inconsistency exists between the characteristics of intellectual property as determined by its classification and the application of intellectual property protection to new types of innovation, classification as a way of representing legal knowledge becomes meaningless. Intellectual property as a class cannot at one and the same time contain concepts of both intellectual property and property if the taxonomy that distinguishes intellectual property from property is to provide any understanding of the nature and origins of different rights of exclusion in these two areas.

:x For exilmple, in both /lanord College (supra notc 22) and Monsomo (infra note 34), the Supreme Court of Canada must address the problem of self-replicating inventions in inlerpreting claims for patent prolection. 
One practical difficulty with this line of reasoning, quite apart from questions of methodology in taxonomy, is that inconsistency is difficult to identify. For example, in relation to the legitimacy of intellectual property protection for biotechnological innovation such as patents for DNA sequences, genes, and cells comprising these genes, the competing claims concerning propertization represent an irreconcilable descriptive disagreement as to whether the definitional boundaries defining the legal class of intellectual property remain intact. We can expect that any debate framed in these terms can continue indefinitely, given the difficulty of locating definitive empirical support for either position.

The more significant difficulty with this line of reasoning is that the focus on the definitional integrity of content-based classes as opposed to the classification process itself means that the terms of the debate are limited to a line-drawing exercise between intellectual property and property. Arguably, however, the process of classification involves reference not only to accepted (albeit contested) justificatory rationales, but also to the dynamic operation of intellectual property in a market context. Indeed, the same could be said of other legal classes in other contexts. What must be kept in mind is that acknowledgment of an additional source of normativity does not preclude definitional rigour. Determinate properties for any legal class can be located at will, when necessary, by bringing a spatial perspective to bear on the problem. This perspective is no more or less accurate simply because it would be possible to reveal characteristics of indeterminacy at the same time by adopting a temporal perspective.

Accordingly, a temporal perspective is essential in identifying contextual sources of normativity that are as much a part of the classification process as justificatory rationales. For intellectual property, a significant contextual source of normativity is market transactions in intellectual assets. With rapid advances in both communications technology and biotechnological innovations, the foundational economic structure of the market is undergoing rapid change. The percentage of wealth held in the form of intellectual property has been increasing at an exponential rate in developed state economies; the value of intellectual property rights often exceeds that of property in corporate asset portfolios, particularly in corporations making extensive use of biotechnological innovation. The definitional line drawing of a utilitarian-based spatial analysis, while necessary, is at best a rough proxy for empirical and/or anecdotal observations concerning the manner in which intellectual property functions to generate value in a post-industrial economy.

The similarity of the legal concepts of intellectual property and property is derived from a shared objective; both intellectual property and property provide holders of these rights with exclusionary value. Exclusive rights of control generate market value by providing the holder with the ability to sell or license these rights, or any portion thereof, for commercial gain. The exclusionary value of intellectual property, in accordance with its predominant justificatory rationale of utilitarianism, is set to the level necessary to balance incentives to create while still promoting a robust public domain. In contrast. the exclusionary value of propery is determined by the market alone, subject to certain regulatory restrictions in the public interest. Thus the default exclusionary value of property is full commercial exploitation, not the more limited scope of commercial exploitation deemed necessary to overcome the public goods problem of intellectual property. 
The legal infrastructure of the market. however, reflects the presumption that rights to property continue to predominate market transactions. This is not the case. Given the increased economic significance of intangible assets, market actors now seck to obtain exclusionary value in relation to intellectual property rights in a manner that permits continuity in the distributive effects of market transactions that previously would have engaged the full exclusion value of property. Quite simply, market actors now seck to use the forms of intellectual property to perform the functions historically associated with property. They are attempting to obtain full commercial exploitation that exceeds the exclusionary value normally associated with term-limited monopoly rights intended solely to address public goods problems.

As with other periods in which significant transitions have taken place in the form in which wealth is held in market economies, legal rules adapt to deal with changing circumstances. Historical transitions, however, are not the focus of a temporal perspective that adopts a synchronic rather than diachronic approach to the classification rules used to allocate legal concepts to legal classes. A temporal analysis observes a class at a given point in time, as does a spatial analysis, but for a temporal perspective the emphasis is on process. not product. In contrast, a spatial analysis focuses on product, not process. By emphasizing definitional distinctions between intellectual property and property as products of legal classification, while ignoring the process by which the classification is made in context as opposed to in the abstract, participants in the propertization debate may be providing the right answers to the wrong questions. Thus the objective of this analysis is to suggest a temporal perspective as a way of moving beyond this definitional impasse by exploring the meaning of intellectual property as a legal class in other than purely spatial terms.

\section{A TEMPORAI. ANAI.YSIS OF "PrOPERTIZATION": The MUTUALITY OF DETERMINACY/INDETERMINACY IN LEGAL CLASSES}

Adopting a spatial analysis, intellectual property is differentiated from property on the basis of decision rules derived from justificatory rationales. In this case, the legitimacy of the claim of propertization is a matter of consistency between a spatial classification and its application to factual circumstances presumed to be an instance of that classification. Definitionally, intellectual property is that which property is not, and when the spatial classification of intellectual property is applied to provide rights of exclusion in a manner more commonly associated with the characteristies of property, an assumption is made that the legal concepts of intellectual property and propeny are combined in the legal class of intellectual property.

An observation of concurrency in legal classes from a spatial perspective may indeed lead to the (mistaken) conclusion that indeterminacy exists, and that such indeterminacy precludes operation of the rule of law. The same is not necessarily the case when observing the same legal classes from a temporal perspective. Temporally, the legal concept of intellectual property is always in flux as it mediates between legal form and markel function. The claim of propertization as a spatial digression reveals nothing of the legitimacy (or illegitimacy) of the process whereby the form of intellectual property, although designed to correct minor market failures in public goods, takes on the function of property in providing the background legal entitlements necessary for the market itself to operate. 
From a temporal perspective, indeterminacy does not affect the legitimacy of legal classification; indeterminacy is an accepted function of the dynamic nature of legal classes operating in a particular context. The purpose of a temporal analysis of the legal class of intellectual property is to observe any exchange of conceptual characteristics that may take place during market-based encounters between the form of intellectual property and the functions normally allocated to property. The legitimacy of this exchange cannot be evaluated with reference to justificatory rationales used to classify intellectual property in spatial terms; encounter and exchange exist temporally, not spatially, and must be evaluated as processes, not products." If a process is examined and an exchange of characteristics judged legitimate, the product of the exchange in the spatial dimension is legitimate as well, even though the product may not be consistent with a legal class' justificatory rationale. That is to say, what may appear to be an indeterminate legal class containing overlapping concepts in the spatial dimension is actually a determinate legal class containing a single concept, albeit a concept modified through a process of constant flux in the temporal dimension.

Recall that to observe wave or particle behaviour in an entity characterized by waveparticle duality, the design of the experiment determines the nature of the phenomenon observed. This is also the case when dealing with the determinate/indeterminate duality of legal classes. When stability is required, legal classes should be observed from a spatial perspective in order to access the determinacy of a single legal concept in a single legal class. When flexibility is required, as is the case when apparent indeterminacy in a legal class cannot be legitimated through traditional justificatory rationales, a temporal perspective will reveal the manner in which legal classes in a constant state of flux are subject to a process of reconfiguration in particular contexts.

Just as the rights and duties associated with the content-based legal classification of property reflect the changing nature of the underlying assets, so do the rights and duties associated with the legal classification of intellectual property. Typically, however, changes to the legal class are attributed to the reiterative process of comparison between the justificatory rationales of intellectual property as a legal concept and its assignment to a unique legal class. Furthermore, the legal classes of intellectual property and property musi be mutually exclusive. Thus, the classification of intellectual property cannot transcend beyond a three-dimensional spatial perspective; recall Waddams' critique of classification that legal meaning cannot exist if multiple legal concepts simultaneously inhabit the same legal class.

This critique of classification, however, does not take into account a temporal analysis. In terms of temporal process, intelleclual property may still perform in many factual circumstances its initial function as a legislative response to market failure. In other factual circumstances, however, particularly those involving new forms of technology, intellectual property has assumed an additional function more typically associated with property, which is to provide the most significant form of background entitlements upon which market transactions depend. As a source of normativity, the market would appcar to assess the legitimacy of intellectual property in this context on the basis of whether intellectual property 
adequately performs the function previously carried out by property, given that the legitimacy of the function in the abstract has already been established.

Without the perspective of a temporal analysis, spatial observation of mutually exclusive legal classes of intellectual property and property will focus ontological debate on the degree of consistency between a legal class and a single source of normativity, that of a given justificatory rationale. Focusing, however, on the measurement of intellectual property's spatial attributes to the exclusion of its temporal attributes risks ignoring the dynamic process whereby intellectual property and property are continually reconfigured within a larger process of reconfiguration between market norms and justificatory rationales. Consider the typical process of legal reasoning that adopts a spatial explanation of changes in modalities of resource allocation such as patent law in response to changing market conditions. The reiterative nature of the relationship between market functions and justificatory rationales for private rights of exclusion is at best implicitly acknowledged. Legal reasoning proceeds on the mistaken assumption that while the market may initiate change, justificatory rationales are the only relevant source of normativity for the development of legal classitication criteria.

The necessarily arbittary point of origin in discussing the implications of this complex reiterative process is technological change. For example, biotechnological innovation generates new assets of value or new methods of using existing assets, thus leading to market transactions involving these new assets or new uses of existing assets. Given that the novel characteristics of these new assets or methods have not been anticipated within the legal regime governing commercial exploitation in this arca, legal uncertainty exists in terms of who has rights to the potential revenue streams. ${ }^{30}$ This leads to competing claims framed within the language of a particular modality of resource allocation such as patent law. Note. however, that claiming patent protection as the appropriate modality is more likely a result of path dependency than any ex ante consideration of available modalities of protection, including those outside the scope of traditional intellectual property law, ${ }^{31}$

In resolving these competing claims, courts and legislators ostensibly refer to justificatory rationales on the basis that modalities of resource allocation have been defined with reference to these rationales. For patent law, this means that courts will refer to both the public goods problem of intangible inventions as well as the bargain theory for those inventions that are not susceptible to reverse engineering. A successful claim for increased protection accords

One particularly compelling example is that of the patenting of higher life forms. The Trode-Re/ared Inellectual Propery Rights (TRIPS) Agreement of the World Trade Organization (WTO) allows Members to exclude higher life forms from patentability. Despite the fact that such patents are granted to Members with the most significant investment in this form of biotechnology, Canada does not yet allow lor the patenting of higher life forms. See WTO. Agreemen on Trode-Related Aspects of

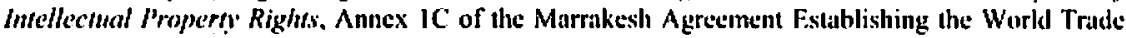
Organization (15 April 1994) 33 I.L.M. 1197, art. 27(2).

3 Note that the competing rights claims to the exclusionary value within a modality of resource allocation may also include claims that the exclusionary salue should not exist, as opposed on whom the exclusionary value should be allocated. For example. the palenting of ecrain biolechnological innovations such as transgenic animals is a highly contros ersial practice, and many constituencies not generally associated with patenting coneems raise both deontological and consequentialist arguments in opposition. In addition, competitors faced with an inlringement suit will often argue against the patentability of the allegedly infringed invention. 
exclusion value to the previously contested asset. Generally, this results in a corresponding decrease in access value, although the decrease is rarely quantified. Positive spillover effects must also be taken into account. In contrast, an unsuccessful claim will tend to lead to an increase in access value with a concomitant decrease in exclusion value. In turn, exclusion value provides an incentive to invest in productive capacity for the purposes of biotechnological innovation which, in turn, leads to further technological change, thus continuing the cycle in perpetuity."2

Technological change also leads to mutual redefinition between market demands and justificatory rationales for intellectual property and property as modalities of resource allocation, in addition to redefinition between the modalities themselves. The market depends upon the allocation of private rights of exclusion, which in turn require a justificatory rationale. These justificatory rationales, however, are not constant for the simple reason that assessment of the legitimacy of market-based transactions in intellectual assets takes place within the context of the market itself. Truly independent assessment does not exist; just as the distributive effects of market transactions are measured against justificatory rationales, these same rationales are being influenced by the cumulative weight of practice in the form of market transactions.

Furthermore, concurrent with this process of mutual redefinition between market demands and justificatory rationales is a second process of mutual awareness and redefinition between intellectual property and property. Intellectual property operates in the market as a form of resource allocation in contact with other forms of resource allocation such as property. Spatially, intellectual property possesses a form, but temporally, it performs a function. While intellectual property exhibits a given spatial form as a matter of two or threedimensional legal classification, it might be performing any number of different functions in a fourth temporal dimension in response to market demands. It is within intellectual property's temporal aspects that one can identify a process of norm creation that does not originate with typical justificatory rationales.

Thus, presumptive indeterminacy of intellectual property as a legal class is derived not from intentional transgression of spatial boundaries, but rather the influence of an unacknowledged source of normativity in the temporal dimension. Courts accept the normativity of expansion, but mistakenly attribute the source to accepted justificatory rationales of intellectual property as a product of classification in the spatial dimension.

1: Note, however, that an increase in exclusion value is not the only relevant incentive for investing in productive capacity. For example, an increase in access value can lower the costs of certain factors of production thus increasing productive capacity; that is to say that all innovation depends to a greater or lesser degree on access to existing knowledgc. Thus, onc of the most significant preoccupations of any justificatory rationale is the appropriate balance between exclusion and access. Operating outside of the traditional framework of market failure, onc can also argue that an increase in access value does not result in a disincentive to engage in productive capacity. but instead an incentive to engage in cooperative productive capacity. Open source software distributed through general public license systems is an example of the degree to which an increase in cooperation value can stimulate innovation. Nole as well that even in cases where market failure cannot be addressed through the provision of incentives, a decrease in exclusion value could still be countered with a corresponding increase in subsidy valuc, i.e., public subsidies to accommodate levels of risk in innovative activities which exceed the capacity of the private sector to manage. 
When the market undergoes rapid change, however, a spatial expression of the legal form of intellectual property as dictated by its justificatory rationale is not necessarily consistent with its temporal function. This inconsistency may be interpreted as indeterminacy in the spatial dimension, but this is not the case if one defines indeterminacy as the inability to associate the characteristics of a particular legal concept with its unique legal class. Examining intellectual property solely from a spatial perspective, without knowledge of the activity taking place in a temporal dimension, one might very well conclude that the presence of attributes traditionally associated with the legal concept of property in the legal class of intellectual property results in indeterminacy in that overlapping legal concepts coexist in a single legal class. One of the most significant contributions of a temporal perspective, however, is the ability to identify sources of normativity derived from classification as a temporal process, thus accounting for the presumptive overlapping of legal concepts. Intellectual property and property do not overlap; intellectual property has simply been reconfigured, although not by a process that is visible from a spatial perspective.

Thus, the legitimacy of a claim of propertization cannot be assessed from a spatial perspective alone. Exclusive rights are indeed granted in accordance with one or more justificatory rationales, but these rationales are a response to and, thus, contingent upon market demands. For example, the market demands that the exclusionary value of the background legal entitlements necessary for the market to function not be decreased simply because the nature of the underlying asset has changed from tangible to intangible form. The result would be an unintentional redistribution of wealth, which would not receive normative acceptance unless the existing distribution of wealth was found to be normatively deficient and in need of reallocation.

In recognizing that temporal contact and exchange between intellectual property and property is not conditioned by preconceptions of the mutually exclusive nature of legal classifications in spatial form, we are able to acknowledge that contextual processes other than justificatory rationales create norms concerning the purposes and functions of intellectual property. What will appear from a spatial perspective to be an inappropriate concurrency of legal concepts within a single class may, when considered in context, be a temporal process of normative acceptance as the form of intellectual property is called upon to perform the function of property. The indeterminacy is real, but relevant only to a temporal and not spatial analysis. Spatially, intellectual property as a legal class still exhibits determinacy for the simple reason that despite appearances to the contrary, the legal concepts of intellectual property and property are not overlapping in the single legal class of intellectual property. An assessment of indeterminacy most likely proceeds from the mistaken assumption that reconfiguration of the legal concept of intellectual property is possible only in the abstract, with reference to one or more justificatory rationales. Determinacy does exist, however, if the reconfiguration process taking place in the context of market transactions in intellectual assets in the temporal dimension is legitimate. The legal class of intellectual property in spatial form still refers to only one legal concept, even though in temporal terms that legal concept might be perpetually in flux.

When viewed from the vantage point of a temporal perspective, intellectual property is not simply a legal classification in spatial form. Intellectual property also exists as a process of classification in flux. A strict demarcation between intellectual property and property exists 
only at that necessary stopping point when legal reasoning demands that the legal class of intellectual property stabilize in spatial form. Even in this spatial form, however, the legal meaning of the class is a function not only of reference to justificatory rationales, but also from the process of encounter and exchange between property and intellectual property in the context of market transactions involving intellectual assets.

\section{REFRAMING; THE "Propertization" DEBATE}

A temporal perspective on classification provides an opportunity to understand legal concepts such as intellectual property as constitutive processes involving multiple sources of normativity located in both space and time. Understood spatially, the legal classification of intellectual property is a product of the justificatory rationales used to determine the appropriate allocation of intangible assets. Intellectual property, however, can also be understood as a process of resource allocation increasingly called upon to perform the same function as property as the proportion of wealth held in the form of intangible assets begins to dominate market transactions.

The result is two-fold. First, in terms of the propertization debate, it would appear that participants from both sides of the property rights/mere negative rights divide advance valid claims. The process of exchange whereby the form of intellectual property performs the functions of property can receive normative acceptance on the basis of the legitimacy of the market function itself. The difficulty, however, is that acceptance on these terms is implicit; courts do not acknowledge that the assessment of legitimacy is made with reference to the reconfiguration of intellectual property in a temporal context as opposed to the legal classification of intellectual property in spatial terms in accordance with an accepted justificatory rationale. Thus the application of the legal rule can appear to transgress a welldefined class boundary, leading to what may well be a mistaken conclusion of legal indeterminacy.

The second result is surprisingly ignored by those who argue against propertization on the basis of consistency of the legal class of intellectual property with one or more justificatory rationales. Emphasis on normative claims against propertization based on the spatial characterization of intellectual property as mere negative rights tends to obscure proprietary characteristics that have distributive effects other than those typically engaged by the incentives-access paradigms of intellectual property law. Neither adversaries of propertization nor courts consider the full range of ethical implications that arise when the legal class of intellectual property is influenced by the concurrent temporal operation of the legal concepts of intellectual property and property as applied to protect the economic value of innovations. 


\section{A. IMPLICIT NORMATIVE TRANSFER IN JUDICIAL. RE.ASONING: MONSANTO V.SCHMEISER}

The significant change brought about by the transition in wealth from tangible to intangible assets arguably calls into question the justificatory rationales of intellectual property laws. These law's have developed in an ad hoc and historically contingent manner, but pursuant to the now predominant justificatory rationale of utilitarianism, they are designed to address market failure in public goods. ${ }^{33}$ This limited ambition must be contrasted with the much broader purpose of property. which is to provide the system of resource allocation upon which an entire market, and not merely isolated market failures, can be based. If market actors and courts accept certain market functions as legitimate - such as the ability to generate maximum return on investment through the commercial exploitation of one's assets - and accept as well, even implicitly, that intangible assets now represent the majority of wealth held for commercial exploitation, an implicit normative transfer may occur.

In certain factual circunstances, such as transactions performed by corporations that have no assets other than exclusive rights in intangibles, the fact that intellectual property carries out proprietary market functions rather than addresses market failures is perceived as legitimate so long as the functions themselves are accepted as legitimate. Normative acceptance occurs not in spatial terms, that is to say by reference to one or more justificatory rationales used to determine the content of particular classes, but temporally as an exchange of values conceming the legitimacy of a given function, whatever might be its modality of expression. Because the exchange of values resulting from this encounter is implicit rather than expressly acknowledged, no attempt is made to determine if such functions remain legitimate when carried out by intellectual property rather than property. In particular, no attempt is made to reconcile these new functions with the spatial form of intellectual property as defined by one or morejustificatory rationales. Thus, any potential conflicts between these two sources of normativity will be neither identified nor addressed.

We can see an example of this temporal process of implicit normative transfer in the reasoning of the majority in the recent Supreme Court of Canada decision of Monsamo Canada Inc. v. Schmeiser. ${ }^{35}$ Monsanto held a patent that claimed, inter alia, a chimeric gene, ${ }^{35}$ a method for inserting the chimeric gene into a plant's DNA, the plant cell in which the chimeric gene had been inserted, and a method for regenerating a glyphosate-resistant plant from the genetically modified cell. ${ }^{36}$ As the founder plant propagates, all of the cells in its progeny will contain the patented chimeric gene, but the patent claims did not extend

33 For a detailed historical account of intellectual property law, sec B3rad Slicrman \& Lionel Bently, The Making of Moderni Infellecfual Property Lan: The Brifish Bxperience. 1760-19/1 (Cambridge: Cambridge Universily Press, 1999). 2004 SCC 34. [2004] I S.C.R. 902 [Mensamo].

35 A chimeric genc is onc that does not exist in a natural state but is instead altered by combining the genctic material of two or more differeme species.

3o The genetic modification increases a crop plant's resistance to herbicides containing glyphosatc. a chemical compound which inhibits an enzyme necessary for a plant's survival. Only unwanted vegetation will be killed off following spraying with herbicide; the genetically altered crop plant will survive. 
to the whole plant or seeds produced by the plant. Such a claim would have been inconsistent with Canadian palent law, which does not include plants and other higher life forms within the scope of patentable inventions.

Monsanto sells the seeds of genetically altered canola through distributors under the trade name of Roundup Ready Canola. The distributors then resell the seeds to farmers pursuant to the terms of a Technology Use Agreement in which the farmers agree: (a) to purchase Roundup Ready Canola lirom authorized seed agents; (b) to use only Roundup herbicide. which is manufactured by Monsanto; (c) to sell the crop only to a commercial purchaser authorized by Monsanto; (d) not to sell or give the seed to any third party; and (e) not to save the seed from the crop for replanting. As with many biotechnological innovations protected by patent rights, the necessity of placing such restrictions on use is due to the self-replicating nature of the invention. Typically, the doctrine of exhaustion would permit farmers to save and reuse the seed purchased from the distributor. The first sale of the invention would have exhausted Monsanto ${ }^{\circ}$ intellectual propenty rights in the invention, leaving the farmer free to use and resell (but not to make) the invention. Applied in these circumstances, however, the doctrine of exhaustion would transfer not only the single instance of the invention to the farmer, but also the means of production, both of which are embodied in the seeds.

Mr. Schmeiser operated a commercial farming operation, and had identified a small number of canola plants on his land grown from Roundup Ready Canola seeds. Mr. Schmeiser harvested these plants, collected their seeds, replanted them, and eventually produced over 1000 acres of Roundup Ready Canola plants. Mr. Schmeiser, however, was not a party to a Technology Use Agreement with any distributor, and Monsanto brought an action against $\mathrm{Mr}$. Schmeiser for patent infringement.

Pursuant to s. 42 of the Patent Act, the inventor has "the exclusive right, privilege and liberty of making, constructing and using the invention and selling it to others to be used." 37 At issue was whether Mr. Schmeiser had "used" the patented invention by harvesting Roundup Ready Canola plants found on his land, replanting these seeds, and then selling the Roundup Ready Canola grown from these seeds. Mr. Schmeiser argued that deciding the case in favour of Monsanto would, in effect, grant Monsanto patent protection not only over the chimeric genc and cells comprising the gene as claimed in its patent, but also over the whole plant. This result would be inconsistent with the Court's prior holding in Harvard College $^{3 k}$ that plants and higher life forms are not patentable.

The majority found in favour of Monsanto, basing its decision primarily on principles of statutory construction which, inter alia, require that "the inquiry into the meaning of 'use' ... must be ... grounded in an understanding of the reasons for which patent protection is accorded." ${ }^{39}$ The majority did make reference, however brief, to the standard utilitarian justification for patent protection: 
lluge investments of energy and money have been poured into the quest for better seeds and better plants. One way in which that investment is protecled is through the fore'nt Act giving investors a monopoly when they creatc a novel and usefül invention in the realm of plant science. such as genctically modilied genes and cells. ${ }^{40}$

The majority's interpretation of "use," however, bears little or no relationship with this utilitarian justificatory rationale. This is demonstrated at the very least by the fact that the majority's interpretation radically transformed the established test for determining an infringing use. $\$$ Traditionally, consideration of infringing use in patent law is a relatively uncomplicated matter. $A$ court must simply decide whether an ostensibly inl'ringing use falls within the scope of the claims. ${ }^{42}$ The emphasis is on the textual analysis of the claims, given the significance of interpretation in defining the scope of the claims.

The majority, however, held that the purpose of the statutory monopoly granted by the Patent $A C t$ is to protect the patentec's "business interests." Accordingly, "use" is defined as any activity by the defendant that furthers its own commercial interests, given that: "If there is a commercial benefit to be derived from the invention, it belongs to the patent holder." Thus, what had been a relatively straight forward comparative analysis of equivalency, literal or substantive, between the impugned activity and the scope of the patentec's claims, now includes a more abstract inquiry into the inherent nature of the impugned activity itself. At issue now is whether the activity results in a commercial benefit that can be causally connected to the use of the invention.

The majority's definition of "use" in s. 42 of the Palent ACl demonstrates that its normative acceptance of Monsanto's claims derives not from its reference to the necessity of a statutory monopoly|to protect private investment in public goods, but in the functions that patents are expected to perform in the changed political economy of the market. The assel portfolios held by corporations such as Monsanto consist almost entirely of the exclusive rights of use granted in the form of patent rights. Thus, corporations such as Monsanto represent the type of market actors who seek to use the form of intellectual property to perform the function typically carried out by property, which is to fully exploit the commercial potential of corporate assets. Full commercial exploitation requires exclusive rights over the whole of the asset at the discretion of the corporation, and not simply over particular uses that are determined by the state to be an appropriate balance of public and private interests in the creation and dissemination of new technology.

Note the significance of the fact that normative acceptance need not be explicit. As noted by Richard Gold, patentees, while framing their claims with reference to accepted justificatory rationales, are actually arguing for control over the entire commercial potential

Wid. at para. 90.

Richard Gold. "Mousanto's gain is everyone else"s pain" The Globe d Mil (24 May 2004) 117. Courts in Canada use a dexirine known as "purposive construction" io interpret palent claims. The doctrine assumes that the pitent is addressed to a "worker skilled in the art." a techuique which prolects the patentee from excessive literalism and the public from overly-broad claims interpretation. Set Fre?

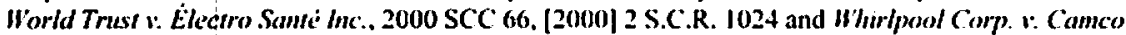
mc.. 2000 SCC 67, [20001 2 S.C.R. 1067.

Supra note 34 at para. 58 . 
of intangible assets. These claims exceed the utilitarian rationale of patent rights as a mere statutory corrective designed to grant control over that portion of the commercial potential necessary to address the market failure associated with the public goods nature of intangible assets:

\begin{abstract}
The argument for greater patent prolection should be understood for what is: an attempt to maximize profit, not to maximize levels of innovation. Clearly, a company would prefer to have as large a monopoly as possible... But patent law is not about individual profit maximization; it is about maximizing the overall level of imnovation in society. The iwo do not necessarily go logether. ${ }^{4}$
\end{abstract}

For corporations such as Monsanto, the legal distinction between intangible and tangible assets has few, if any, normative implications. To these companies, assets are property and property is to be commercially exploited to the fullest extent possible. In Canada and the United States, corporate law itself demands that directors and officers place the welfare of the firm above any other countervailing interests. " Notwithstanding the various possible interpretations of what it might mean to maximize the welfare of a firm, acting in the best interests of the firm requires some degree of profit maximization. ${ }^{16}$ Thus, the relevance of Gold's argument to this analysis is that while incentives may lead to innovation, innovation leads to profit and the profit motive itself is the primary short-term concern of individual corporations, not the optimal level of innovative activity.

In the political economy of the market, the profit motive has normative acceptance and corporations should not be expected to engage in self-denial or to consider aggregate as opposed to individual welfare maximization when pursuing new claims for patent protection. That is the role of legislators and courts when drafting and interpreting patent legislation. Thus, the demands of individual actors in the market, however valid within the political economy of the market itself, must be reconciled with one or more accepled justificatory rationales of patent protection.

The difficulty is that courts appear to be implicitly responding to the normativity of the market in the form of the profit motive even as they refer expressly to traditional justificatory rationales in resolving disputes between the parties. Recall that the majority in Monsanto held that a patentee is entitled to any commercial benefit that can be derived from an

E. Richard Gold. "Biomedical Patents and Ethics: $\Lambda$ Canadian Solution" (2000) 45 McGill L.J. 413 at 423.

4s See, e.g., Canada Business Corporations ACr. R.S.C. 1985, c. C-44, s. $122(1)$ (a): "Every director and officer of a corporation in exercising their powers and discharging their duties shall act honestly and in good faith with a view to the best interests of the corporation." See also art. 322 C.C.Q.: "L'administrateur doil agir avec prudence et diligence. Il doil aussi agir avec honnêtelè et loyauté dans l'intereit de ta personnce morale." For an interesting debate on whether acting in the best inlerests of the corporation should mean more than maximizing firm profits and thus sharcholder wealth, see Ronald M. Green, "Slareliolders as Stakelıolders: Changing Metaphors of Corporale Governatuce" (1993) 50 Wash. \& Lee L. Rev. 1409 and Stephen M. Bainbridge, "In Defense of the Shareholder Wealth Maximization Norm: A Reply to Professor Green" (1993) 50 Wash. \& Lee L. Rev. 1423.

to The term "profit maximization," however, remains open to interpretation. Ste, e.g. Reinier Kraakman et al. The Anatomy of Corporate Lan: A Comparative and Functional Approach (Oxlond: Oxford University Press, 2004) at 17-19. 
invention. ${ }^{47}$ Yet, the same majority also reasoned that its decision was based on the utilitarian rationale of patent protection, which justifies the protection of incentives only, not profitmaximization. The result is presumptive indeterminacy of the legal class of intellectual property from a spatial perspective. How could it be otherwise? If the attributes of the class do not appear to be those of intellectual property, they must belong to some other legal concept, such as property.

This indeterminacy, however, is entirely illusory as the conclusion is based on the mistaken assumption that the only source of normativity for the legal class of intellectual property is an accepted justificatory rationale. What remains unobserved, and thus unacknowledged, is that changes in the spatial form of intellectual property need not be consistent with a justificatory rationale for the class to remain determinant. If changes originating in a temporal context are considered legitimate, then the legal class of intellectual property remains determinate in spatial form. Attributes that may appear from a spatial perspective alone to be those of property are actually those of a temporally reconfigured legal concept of intellectual property.

\section{B. ETHICAL IMPLICATIONS: HARVARD COLLEGE V. CANADA (COMMISSIONER OF PATENTS)}

One of the most significant implications of an implicit normative transfer between the functions of property and the form of intellectual property is that the existence of proprietary attributes transferred to the legal concept of intellectual property in certain market contexts remains unacknowledged. This obscures the extent to which intellectual property increasingly raises ethical considerations other than those derived from the incentives-access paradigms. The reasoning of both the majority and dissenting opinions of the Supreme Court of Canada in Harvard College ${ }^{48}$ provide a timely example.

Harvard College had applied for, and had been refused, a patent for a so-called oncomouse. According to Harvard College, it had created a species of oncomouse when it genetically engineered certain mice to be susceptible to cancer in order to increase their utility as laboratory research animals. At issue was whether higher life forms such as the genetically altered oncomouse were included within the scope of patentable subject matter pursuant to Canada's Patem Act." The Patent Examiner allowed the process claims for creating the genctic modifications, but did not allow a product claim over the genetically modified mouse itself. According to the Patent Examiner, this would amount 10 granting a patent over a higher life form, and higher life forms are not within the statutory definition of patentable subject matter. The Commissioner of Patents agreed and Harvard College subsequently sought judicial review.

After proceeding through both the trial and appellate divisions of the Federal Court of Canada, the case was heard by the Supreme Court. Given that all the rights and obligations of patent law originate in the Patent Act, the case involved statutory interpretation of the

Sitpra note 34 at para. 58.

Sirpru note 22.

Siupra note 37. 
definition of an "invention" in terms of the scope of patentable subject matter. By a narrow majority of 5-4, Bastarache J. held that the statutory definition of patentable subject matter did not anticipate, and thus did not include, higher life forms. Note that the majority did not decide that higher life forms cannot be patented, only that they did not amount to "inventions" pursuant to the current legislation. If higher life forms were to be subject to patent protection, Parliament would need to enact the necessary amendments. Justice Binnie, writing in dissent, would have found the definition of "invention" sufficiently broad to include higher life forms.

One point that both the majority and dissent agreed upon, and that is relevant for this analysis, is the appropriate characterization of patent protection as a mere negative right to exclude. The Commissioner of Patents and several intervenors raised ethical objections to the patenting of higher life forms based on concerns for animal welfare and animal rights. Both the majority and dissenting opinions agreed, however, that a patent does not provide the patentee with an affirmative right of use. Accordingly, patent law is ethically neutral. Ethical concerns arise not as part of the patenting process, but during upstream research and development and downstream commercialization of the patented processes and products. Ethical issues are important and should be addressed, but through targeted legislation external to the patent regime rather than as a condition of patentability. ${ }^{50}$

Neither the majority nor dissenting opinions express any definitional uncertainty as to the nature of the rights granted and functions performed by intellectual property law. Intellectual property grants mere negative rights; a patent grants only the right to exclude others from making, using, or selling the claimed invention. Such negative rights are not equivalent, in either form or function, to the affirmative rights granted by property. Thus, the ethical debates typically carried out by judges (particularly common law judges) in determining whether to extend property to include new assets is entirely absent from the reasoning. "1 As stated by Binnic J. in dissent: "This is not to say that patents are 'neutral', or have no link to the ethical and social issues raised by the interveners. It is to say that those issues transcend the narrow question of patentability."

Thus, Harvard College provides another illustrative example of the limitations of legal reasoning conducted in purely spatial terms, whether two or three-dimensional, without

Whether the patent system is the most appropriate regulatory site for governing associated ethical concerns is a matter of debale. As Binnie J. notes, in dissent, regional and intemational trade agreements such as NAFTA (North American Free Trade Agreement Berween the Government of Canada, the Government of Mexico and the Government of the United Stutes, 17 December 1992, Can. T.S. 1994 No. 2, 32 I.L.M. 289 (entered into force I January 1994)) and TRIPS, supra note 30, permit stales to exclude from patentability inventions that, in their commercial exploitation, would be contrary to ordre public or morality. Many jurisdictions do include an ordre public and morality clause in patent Icgislation, such as the Eirropean Paten Convemion. No such clause exists, however, in the Canadian Pusent Act. As noted by Bastarache J. for the majority, the Canadian Biotechnology Advisory Committec (CBAC) recommends that the significant cthical isstes raised by the patenting of higher life forms be addressed by Parliament (although $\mathrm{CB} \wedge \mathrm{C}$ also recommends that patents be made available for higher life lorms). Parliament has yet to act, however, in response to the decision in /larvard College. concerning the ethies of granting a person property rights in cells excised from their body in Moore' $:$ Regents of the University of Caljformia, 793 P.2d 479 (Cal. Sup. C1. 1990).

s. Supra nole 22 at para. 65. 
recognition of the normative influence of intellectual property operating in a temporal context. Those arguing against propertization would do well to expand their analysis of distributive effects beyond the typical public/private divide in terms of distribution of resources to consider non-economic implications as well. In spatial terms, patent rights do appear to be mere negative rights, given that the objective of intellectual property legislation is to provide a time-limited monopoly sufficient to address market failure in public goods. Patents are neither intended nor designed to provide inventors with full rights of commercial exploitation. In fact, as is evident from the decision in Harvard College, even as rights holders argue about what amounts to proprietary protection, they simultaneously rely on the characterization of patents as mere negative rights in arguing against the inclusion of ethical considerations as a criterion of patentability.

Characterizing intellectual property rights as mere negative rights to exclude obscures the extent to which the exercise of these rights raises ethical concerns apart from achieving the appropriate balancing of private and public interests within intellectual property policy. Viewed from a temporal perspective, patents exist as a dynamic process of resource allocation in market transactions involving controversial assets created by biotechnological innovation. In this context, patents perform functions and lead to distributive consequences which are similar to those associated with property.

\section{Conclusion}

We began this analysis with an inquiry as to whether legal classification can adequately represent legal knowledge. In particular, disagreement exists as to whether the complexity of the relationship between legal reasoning and legal knowledge can ever be represented by a taxonomy that exists in two-dimensional spatial form. In other words, is cartography an adequate metaphor for explaining the manner in which classification represents legal knowledge?

One difficulty with phrasing the question in these terms is a tendency to confuse the explanatory metaphor with that which is to be explained. Assuming that legal knowledge is too complex to be explained with reference to a metaphor of mapping docs not call into question the adequacy of classification, but merely the limitations of spatial representations of legal classifications. The obstacle thought to preclude the use of classification as a way of representing legal knowledge is the complexity of legal reasoning. Classification presumably cannot place multiple legal concepts within a single legal class and still retain an organizational structure capable of providing determinacy.

From a temporal perspective, we can see that ontological difficulties such as the propertization debate cannot be resolved by focusing on the definitional properties of the mutually exclusive legal classes of intellectual property and property in spatial form. Instead, attention should be directed to the manner in which the form of intellectual property is increasingly called upon to perform the linctions traditionally associaled with property in transactions involving biotechnological innovation. When classification is presumed to exist only as the product of one or more justificatory rationales, mutually exclusive classifications musı necessarily result as a justificatory rationale cannot provide any sense of justification 
if it provides a classification by which intellectual property is simultancously that which it is and that which it is not.

The reality, however, of concurrency of legal concepts as a process of legal reasoning can be accommodated within legal classification by adopting a temporal perspective. From a temporal perspective, the focus is not on a legal class in spatial form, but on the encounter and exchange of values between the legal concepts of intellectual property and property as these concepts operate in the context of the political economy of the market. Given the increasing percentage of wealth represented by intangible as opposed to tangible assets, the spatial form of intellectual property is increasingly called upon to perform the temporal function of property, which is to provide the background legal entitlements upon which the operation of the market depends. Thus, from a temporal perspective, we are able to take account of the concurrent operation in context between legal concepts, that of intellectual property and property. The legal class of intellectual property, however, maintains its taxonomic integrity because concurrency exists in a temporal as opposed to spatial dimension.

The contribution of a temporal approach to classification is the realization that intellectual property has both spatial and temporal attributes, thus providing an explanation for the coexistence of determinacy (in the form of mulually exclusive legal classes) and indeterminacy (in the form of overlapping legal concepts) in legal classification. Temporally, intellectual property exists as a process of classification in flux, and a fixed line of demarcation between intellectual property and property comes into existence only when legal reasoning demands that the legal class of intellectual property stabilize in spatial form. Even in spatial form, however, the class of intellectual property derives meaning not only from reference to justificatory rationales, but also from the process of encounter and exchange between property and intellectual property in transactions involving biotechnological innovation. The difficulty is that one can observe this process of encounter and exchange only from a temporal perspective. Thus, we require the addition of a fourth, temporal dimension, to the analysis of legal classification in order to realize that what might appear to be indeterminacy in spatial form is simply the unacknowledged transfer of attributes between property and intellectual property in a temporal, market-based context. 